\title{
Self-Perception and Training Perceptions on Teacher Digital Competence (TDC) in Spanish and French University Students
}

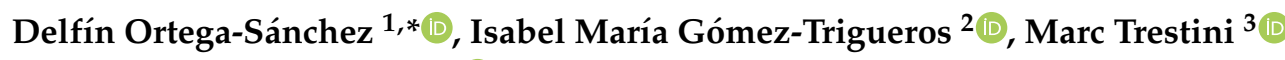 \\ and Carlos Pérez-González 4 (D) \\ 1 Department of Specific Didactics, Faculty of Education, University of Burgos, 09001 Burgos, Spain \\ 2 Department of General Didactics and Specific Didactics, Faculty of Education, University of Alicante, \\ 03690 Alicante, Spain; isabel.gomez@ua.es \\ 3 Institut National Supérieur du Professorat et de l'Éducation | INSPÉ de l'Académie de Strasbourg, \\ Université de Strasbourg, BP 40102-F-67024 Strasbourg, France; marc.trestini@espe.unistra.fr \\ 4 Department of Philology, Faculty of Humanities and Communication, University of Burgos, \\ 09001 Burgos, Spain; cperez@ubu.es \\ * Correspondence: dosanchez@ubu.es; Tel.: +34-947-111-832
}

Received: 20 August 2020; Accepted: 16 October 2020; Published: 17 October 2020

\begin{abstract}
The purpose of this research is, on the one hand, to analyze the self-perception of future teachers of childhood education and primary education, and those studying for a master's degree in secondary education teacher training on their Teacher Digital Competence (TDC), as well as the potential influence of gender, country and university institution of origin in their representations. On the other hand, it seeks to analyze the perception of future teachers on the TDC of their university trainers (formative perception). In accordance with these aims, a quantitative methodology of a non-experimental nature and of a prospective cross-sectional ex post facto approach has been used. A total of 428 students from two Spanish universities and from a French university agreed to participate in the research. The results report a positive and differential self-perception by gender of the TDC acquired and unfavorable perceptions of the digital competences of their teachers. These results confirm the need to improve the technological-manipulative and didactic training of university teachers, and to adapt the teaching competences to the demands of the Information and Communication Society (ICS) and to the guidelines of the Common Digital Competence Framework.
\end{abstract}

Keywords: teacher training; teacher digital competence; educational technology; self-perception

\section{Introduction}

The Information and Communication Society (ICS) has led to important transformations in the field of education, generating new models and methodologies of teaching and learning (E-Learning) with technology at all educational levels. However, the mere inclusion of Information and Communication Technologies (ICTs) has not been enough to promote a real and deep change [1]. In this sense, the involvement of all agents involved in educational processes is still demanded, paying special attention to the role of teachers and their digital competence [2], which is essential in the operational and effective implementation of technological resources in the classroom. In fact, ICTs have allowed the emergence of new models of teaching-learning processes where the teacher is no longer the protagonist of the process but guides the student in learning skills [3]. Its inclusion has favored the promotion of a new paradigm in education that requires the development and acquisition of digital competences and skills by future teachers [4]. 
Although there are many and varied lists of teaching skills for primary [5], secondary [6] and university teachers [7], it is the Teacher Digital Competence (TDC) that acquires a prominent relevance in the educational contexts of the 21st century [8,9].

The 2006 European Recommendation defines digital competence as involving the "safe and critical use of Information Society Technologies (ISTs) for work, leisure and communication ( ... ) [for the purpose of] obtaining, evaluating, storing, producing, presenting and exchanging information, and communicating and participating in collaborative networks over the Internet" [10]. One of the most recent definitions of this competence, fundamental and transversal in the development of any community program for the effective integration of technology in any training environment [11], is provided by the European recommendation of 2018 [12], regarding the key competences for lifelong learning: "Digital competence implies the safe, critical and responsible use of digital technologies for learning, at work and for participation in society, as well as interaction with these technologies. It includes information and data literacy, communication and collaboration, media literacy, digital content creation (including programming), security (including digital well-being and cyber-security related skills), intellectual property issues, problem solving and critical thinking" (p. 9).

This definition specifies the main skills of digital competence, with an emphasis on information and communication management in social environments. In this sense, the TDC can be defined as the set of knowledge, skills and attitudes needed to be functional in a digital teaching environment.

Aware of the need for training in TDC, the National Institute of Educational Technologies and Teacher Training (INTEF) has developed a Common Framework for Digital Competence [13], which identifies five areas for the full training of teachers in this competence (pp. 15-67), which are completed with those defined in the European Framework for the Digital Competence of Educators (DigCompEdu) [14]:

1. Information and information/media literacy-related to aspects of the location, retrieval, storage, organization and critical analysis of digital content.

2. Communication and collaboration-referring to the ability to share online resources and interact in networks through digital tools, in order to foster communication, collaboration and civic participation.

3. Creation of digital content_reworking existing content and taking into account intellectual property rights and licenses of use.

4. Data security and personal security/well-being - taking action to secure the physical, psychological, and social well-being of students when using digital technologies. Empowers students to manage risk and use digital technologies to support their own social, psychological, and physical well-being.

5. Problem solving - adapting digital resources to the needs of each moment and purpose, resolving manipulative conflicts and proposing the creative use of digital resources.

These guidelines, aligned with those included in area 6 of the European Framework for the Digital Competence of Teachers (DigCompEdu) (information, communication, creation, responsible use, and problem solving) [14], should be a priority in the curricula of future teachers and its promotion is essential to achieve adequate training in TDC, capable of allowing optimal mastery of technological resources for teaching practice [15-18] (Table 1).

In this line, actions of special formative importance stand out, such as the R+D+I (Research, Development and Innovation) project Competence in audiovisual communication in a digital environment [19], whose intention was to carry out a diagnostic study of the educational and communicative needs in the area of, among others, higher education, or the Erasmus+ project Developing ICT in Teacher Education, whose objective is to learn about and go deeper into teacher training for the acquisition of digital competences. 
Table 1. Integration of competence areas between the Common Framework for Digital Competence (INTEF) and the European Framework for the Digital Competence of Educators (DigCompEdu)/Competence Area 6 (Facilitating Students' Digital Competence) for the development and acquisition of digital competences in a complete teaching-learning process.

\begin{tabular}{|c|c|}
\hline $\begin{array}{l}\text { Common Framework for Digital Competence } \\
\text { (INTEF) }\end{array}$ & $\begin{array}{l}\text { European Framework for the Digital Competence } \\
\text { of Educators (DigCompEdu) }\end{array}$ \\
\hline $\begin{array}{l}\text { Competence area } 1 \text {. Information and } \\
\text { Information Literacy. } \\
\text { Identifying, locating, obtaining, storing, organizing } \\
\text { and analyzing digital information, data and digital } \\
\text { content, assessing their purpose and relevance for } \\
\text { teaching tasks. }\end{array}$ & $\begin{array}{l}\text { Competence area 6.1. Information and media literacy. } \\
\text { Incorporate learning activities, tasks, and assessments } \\
\text { that require students to articulate information needs; } \\
\text { find information and resources in digital } \\
\text { environments; organize, process, analyze, and } \\
\text { interpret information; compare and critically evaluate } \\
\text { the credibility and reliability of information and } \\
\text { its sources. }\end{array}$ \\
\hline $\begin{array}{l}\text { Competence area 2. Communication } \\
\text { and collaboration. } \\
\text { Communicating in digital environments, sharing } \\
\text { resources through online tools, connecting and } \\
\text { collaborating with others through digital tools, } \\
\text { interacting and participating in communities and } \\
\text { networks; intercultural awareness. }\end{array}$ & $\begin{array}{l}\text { Competence area 6.2. Digital communication } \\
\text { and collaboration. } \\
\text { Incorporate learning activities, homework } \\
\text { assignments, and assessments that require students to } \\
\text { effectively and responsibly use digital tools for } \\
\text { communication, collaboration, and civic engagement. }\end{array}$ \\
\hline $\begin{array}{l}\text { Competence area 3. Creation of digital content. } \\
\text { Creating and editing new digital content, integrating } \\
\text { and reworking previous knowledge and content, } \\
\text { making artistic productions, multimedia content and } \\
\text { computer programming, knowing how to apply } \\
\text { intellectual property rights and use licenses. }\end{array}$ & $\begin{array}{l}\text { Competence area } 6.3 \text { Creation of digital content. } \\
\text { Incorporate homework and learning activities that } \\
\text { require students to express themselves through } \\
\text { digital media and to modify and create digital content } \\
\text { in different formats. Teach students how copyright } \\
\text { and licensing apply to digital content, how to } \\
\text { reference sources and apply licenses. }\end{array}$ \\
\hline $\begin{array}{c}\text { Competence area } 4 \text {. Security. } \\
\text { Protection of information and personal data, } \\
\text { protection of digital identity, protection of digital } \\
\text { content, security measures and responsible and safe } \\
\text { use of technology. }\end{array}$ & $\begin{array}{l}\text { Competence area 6.4. Welfare. } \\
\text { Take measures to ensure the physical, psychological, } \\
\text { and social well-being of students when using digital } \\
\text { technologies. Empower students to manage risk and } \\
\text { use digital technologies to support their own social, } \\
\text { psychological, and physical well-being. }\end{array}$ \\
\hline $\begin{array}{l}\text { Competence area } 5 \text {. Problem solving. } \\
\text { Identify needs for the use of digital resources, make } \\
\text { informed decisions about the most appropriate } \\
\text { digital tools according to the purpose or need, solve } \\
\text { conceptual problems through digital media, use } \\
\text { technologies creatively, solve technical problems, } \\
\text { update their own competence and that of others. }\end{array}$ & $\begin{array}{l}\text { 6.5 Digital problem solving. } \\
\text { Incorporate learning and assessment activities that } \\
\text { require students to identify and solve technical } \\
\text { problems or creatively transfer technological } \\
\text { knowledge to new situations. }\end{array}$ \\
\hline
\end{tabular}

In the socio-cultural and educational context of the ICS, it is essential that new generations of teachers acquire an adequate level of digital competence [7]. This training takes the form of acquiring skills that will enable future teachers to access and create new digital content and resources, and to critically discern their didactic use. These changes will only be possible if the current university teachers are equipped with digital teaching skills that will achieve a comprehensive training of students. The recognition of the use of technologies as one of the competences of today's teachers that is explicitly stated in the guidelines of the European Higher Education Area, and it is one of the key competences of European curricula at all educational levels [20]. It is therefore essential to know both the self-perceptions of future teachers regarding the level of TDC acquired in their studies and their beliefs and degree of self-confidence in their ability to take the necessary actions to achieve specific teaching objectives with technology [21].

In this context, the objective of this research is to deepen the knowledge of TDC, in particular, in the specific field of training of future Spanish and French teachers of pre-school, primary and secondary 
education, in order to know their self-perceptions about the manipulative and didactic competences in the use of technological resources for teaching, and in their training as teachers, according to gender, country and university institution. It also seeks to identify the value that students give to the digital competences of their university trainers.

\section{Materials and Methods}

\subsection{Research Design}

The research uses a descriptive, correlational and inferential ex post facto approach, with the intention of finding out the self-perceptions of future teachers about their TDC according to gender, country and university institution of origin, and their perceptions of their trainers. A non-experimental exploratory research design was employed, using the questionnaire as a data-collection instrument [22]. The study followed four work phases: A theoretical review of the previous scientific literature on digital competence and, in particular, TDC and its potential link to gender, country, and institution. The gender factor has generated one of the most relevant research concerns in the analysis of the development and acquisition of digital competences in the educational field [23-26]. The interest in identifying differences in terms of the country and university institution of the participating students lies in their participation in educational innovation projects (in the process of initial development) with homogeneous purposes and, therefore, is not adapted to their potential national particularities and institutional academic policies (first phase); the design and validation of the instrument based on the collaboration of faculty from other national and international universities (second phase); the collection and emptying of information (third phase); the analysis and interpretation of the data obtained and elaboration of proposals for the improvement of initial teacher training (fourth phase).

\subsection{Participants}

The selection of participants was made through a convenience sampling [27], based on the ability of the research group to access the population under study. A total of 428 students-future teachers in initial training, enrolled in the participating Universities and in four Educational Innovation Projects coordinated by the Universities of Alicante and Burgos (Spain) — participated in the research. The selective amplitude of the participating sample, coming from three university degrees (childhood education, primary education and master's degree in secondary education) resulted in the need to make the most complete approach possible to the self-perceptions and training perceptions of the future teachers in TDC, regardless of the educational level. With an margin of error of $5 \%$ and a confidence level of $99 \%$, the sample is considered significant with respect to the total population $(N=1189)$ [28], and is composed of 336 women (78.5\%) and 92 men (21.5\%) (Table 2). The age range was between 18 and over 40 years, distributed as follows: first year of bachelor's degree (25.5\%); second year of bachelor's degree (19.6\%); third year of bachelor's degree $(36.4 \%)$ and fourth year of bachelor's degree/first year of master's degree (18.5\%).

Table 2. Descriptive results (frequencies and percentages) by university institution and gender.

\begin{tabular}{cccccccc}
\hline \multirow{2}{*}{ Center } & \multirow{2}{*}{$\mathrm{C}$} & $\boldsymbol{n}$ & $\mathbf{\%}$ & \multicolumn{4}{c}{ Gender } \\
\cline { 5 - 8 } & & & & $\boldsymbol{M}$ & $\%$ & $\boldsymbol{W}$ & $\%$ \\
\hline University of Alicante & $1-4 \mathrm{~B}, 1 \mathrm{M}$ & 153 & 35.7 & 31 & 33.6 & 122 & 36.3 \\
University of Burgos & $1-4 \mathrm{~B}$ & 102 & 23.8 & 19 & 20.6 & 83 & 24.7 \\
INSPÉ de l'Académie de Strasbourg & $1-4 \mathrm{~B}, 1 \mathrm{M}$ & 173 & 40.4 & 42 & 45.8 & 131 & 39 \\
Total & 14 & 428 & 100 & 92 & 100 & 336 & 100
\end{tabular}

C.: Participating courses; 1-4: first, second, third and fourth course; B.: bachelor's degree course; M.: master's degree. 


\subsection{Instrument}

For the collection of data, the Ortega-Sánchez and Gómez-Trigueros [18] questionnaire was adapted, revised in other studies [29], and prepared in accordance with the guidelines of the Common Framework for Digital Competence [13]. The instrument consists of 16 items measured on a 5-point Likert scale, where the value 1 corresponds to Strongly Disagree and the value 5 to Strongly Agree with a neutral midpoint (3). The scoring of the scale to 5 possible points was considered sufficient to allow a clear positioning of the future teachers in relation to their TDC and that of their university teachers. The selection of this type of scale was based on its ability to measure attitudes, perceptions or related traits [30], assessing the intensity of student identification with the proposed statements. It was organized into three content blocks: the first, dedicated to the socio-demographic characteristics of the sample (items 1-4); the second, referring to teaching skills and, in particular, to the students' TCD (items 5-11/first subscale); and the third, relating to the teachers' TDC (items 12-16/second subscale).

Once the viability of the factorization of the data returned by the instrument was verified (Kaiser-Meyer Olkin [KMO] $=0.821$; Barlett's sphericity test, $p=0.000$ ), an Exploratory Factorial Analysis (EFA), applied by means of the method of principal components analysis and varimax rotation, revealed a solution of two latent factors with auto-values greater than one, explaining the totality of the variance and coinciding with the two subscales/theoretical dimensions mentioned. The re-validation process of the instrument consisted of a pilot test or cognitive pre-test, based on the distribution of a draft prepared by the responsible researchers to 45 subjects in the sample. Aspects such as the correction of the statements, clarity in their understanding and the adequacy of the extension; the pertinent categorization of the answers; the existence of psychological resistance or rejection of certain questions and the logical arrangement of the construct, among others, were pointed out. The method applied was based on informal interviews and on the assessments made by the participants in the study.

With the purpose of analyzing the quality and agreement between the attributes of the items that make up the questionnaire (clarity in the wording, internal coherence, induction of biased response, use of appropriate language), we calculated Kendall's coefficient of concordance ( $W$ ), based on the assessments expressed by six independent expert judges, from four Spanish universities (University of Alicante, University of Murcia, University of Burgos, and University of the Balearic Islands), one Portuguese university (University of Porto) and one French university (ESPE de 1'Académie de Strasbourg), in a range of 1 to 5 points. The results show the existence of a high index of concordance and significant homogeneity between the assigned ranges $(W=0.834, p=0.000)$, confirming the content validity of the proposed instrument.

Finally, to check the internal consistency and reliability of the instrument, Cronbach's alpha test was applied to each subscale of the study, which returned a result of $\alpha=0.714$ (self-perceptions in teaching competence and TDC) and from $\alpha=0.891$ (formative perceptions), values considered acceptable for the type of study proposed.

\subsection{Procedure and Data Analysis}

The study was carried out during the first semester of the 2019-2020 academic year in three faculties of education belonging to two Spanish universities (University of Alicante and University of Burgos) and one French university (INSPÉ de l'Académie de Strasbourg). The questionnaire was distributed by e-mail, with the prior authorization of the academic heads of the participating university institutions, through the free Google Forms application. The students received the questionnaire in their institutional mail, in Spanish and in French, and were informed of the objective of the research, as well as of the confidentiality with which their answers would be processed.

For the analysis of the data, descriptive statistical analyses were performed (mean and standard deviation) and, once the normal distribution of the data (Kolmogorov-Smirnov test) and the homogeneity of its variances (Levene's test) were confirmed, inferential analyses (independent samples t-test, one-way analysis of variance [ANOVA], and effect sizes by calculating the Cohen's $d$ ) were conducted in order to compare and assess the existence of significant differences according to 
gender, country and the university institution of the participants, in relation to the three blocks under study. Likewise, in order to know the relationship between students' self-perception about their TDC and the perception about their teachers' training capacity in the same competence, a Pearson linear correlation analysis was carried out. This analysis, typical of the level of relational research, does not seek to evidence causal relationships, but to demonstrate the existence of relationships of bivariate interdependence between the random variables under study. The statistical software SPSS v. 23 was used to process the data.

\section{Results}

\subsection{Descriptive Analysis}

The results obtained in items $C 5$ and $C 6(M \geq 4.10 ; S D \leq 0.783)$ confirm that the students' perception of their TDC is positive, highlighting the special importance given to teacher training (Table 3).

Table 3. Descriptive results.

\begin{tabular}{|c|c|c|c|}
\hline \multicolumn{2}{|r|}{ Subscale 1: Teaching Skills and TDC (Future Teachers) } & \multirow{2}{*}{$\frac{M}{4.51}$} & \multirow{2}{*}{$\frac{S D}{0.557}$} \\
\hline C5 & My studies meet my expectations in terms of my training in teaching skills. & & \\
\hline C6 & $\begin{array}{l}\text { I consider training in teaching skills and, in particular, in digital teaching skills to } \\
\text { be important in both my initial and in-service training. }\end{array}$ & 4.74 & 0.484 \\
\hline C7 & $\begin{array}{l}\text { I know and am able to correctly use office programs such as word processors, } \\
\text { spreadsheets, images and presentations. }\end{array}$ & 4.35 & 0.703 \\
\hline $\mathrm{C} 8$ & $\begin{array}{l}\text { I know, and I am able to manage and distribute properly educational content } \\
\text { through Web } 2.0 \text { applications (Blogs, Wikis, Forums, MOOC, Drive, Dropbox, } \\
\text { Prezi, Slideshare, Moodle, Flickr, YouTube and Digg, among others). }\end{array}$ & 4.08 & 0.703 \\
\hline C9 & $\begin{array}{l}\text { I am able to search and discriminate information-content on the web for didactic } \\
\text { use. }\end{array}$ & 4.26 & 0.619 \\
\hline $\mathrm{C} 10$ & $\begin{array}{l}\text { I know the basic software and hardware (office suite, Google browser and } \\
\text { similar) needed for my future teaching work, and I am able to generate teaching } \\
\text { content from these resources. }\end{array}$ & 4.24 & 0.806 \\
\hline \multirow[t]{2}{*}{$\mathrm{C} 11$} & I have the training to properly implement ICT to teach content in the classroom. & 4.09 & 0.786 \\
\hline & Subscale 2: TDC (University Teachers) & $M$ & $S D$ \\
\hline $\mathrm{C} 12$ & My university professors have sufficient training in digital teaching skills. & 3.27 & 0.702 \\
\hline $\mathrm{C} 13$ & $\begin{array}{l}\text { My university teachers are sufficiently skilled in the use of ICT as a pedagogical } \\
\text { and educational resource. }\end{array}$ & 3.21 & 0.714 \\
\hline $\mathrm{C} 14$ & $\begin{array}{l}\text { My university teachers implement ICTs correctly in my curriculum and in their } \\
\text { training practice. }\end{array}$ & 3.17 & 0.721 \\
\hline C15 & $\begin{array}{l}\text { My university professors have provided me with appropriate models that } \\
\text { combine content, technology and didactics for my future teaching work. }\end{array}$ & 3.22 & 0.703 \\
\hline $\mathrm{C} 16$ & $\begin{array}{l}\text { My university professors have sufficient training and knowledge about } \\
\text { technological tools and resources for teaching, such as those integrated in web } \\
2.0, \text { MOOCs, virtual simulators and augmented reality, the portfolio, e-activity, } \\
\text { QR codes and Google Earth, among others. }\end{array}$ & 3.12 & 0.701 \\
\hline
\end{tabular}

M: mean; SD: standard deviation

The participants consider that they achieve sufficient training in the use of basic technological tools $(M=4.35, S D=0.703 ; M=4.24, S D=0.806)$ and in the adequate implementation of technologies for educational purposes in the classroom $(M=4.08, S D=0.703 ; M=4.09, S D=0.786)$, through the critical selection of digital content for its potential didactic use $(M=4.26, S D=0.619)$.

In relation to the digital teaching qualification of their teachers, the results show a negative perception of their manipulative skills in ICT $(M \geq 3.27, S D=0.702 ; M \geq 3.12, S D=0.701)$, and the didactic introduction of technological resources in teaching-learning processes $(M \geq 3.21, S D=0.714$; $M \geq 3.17, S D=0.721 ; M \geq 3.22, S D=0.703)$. 


\subsection{Comparative Analysis by Gender}

The results show the existence of statistically significant differences in the importance given to training in teaching skills and in TDC $(t=1.984, p=0.009)$, as well as in the knowledge of the handling and manipulation of Web 2.0 applications for the treatment of didactic content according to gender $(t=1.991, p=0.045)$ (Table 4$)$.

Table 4. T-test and ANOVA test according to gender.

\begin{tabular}{|c|c|c|c|c|c|c|c|}
\hline \multirow{2}{*}{ V. } & \multicolumn{2}{|c|}{ Gender } & \multirow[b]{2}{*}{$t$} & \multirow[b]{2}{*}{$p$} & \multirow[b]{2}{*}{$F$} & \multirow[b]{2}{*}{$p$} & \multirow[b]{2}{*}{$d$} \\
\hline & $W$ & $M$ & & & & & \\
\hline C5 & 3.50 & 3.55 & -0.478 & 0.615 & 0.228 & 0.633 & \\
\hline C6 & 4.96 & 4.21 & 1.984 & $0.009 * *$ & 3.936 & $0.048 *$ & 1.55 \\
\hline C7 & 4.30 & 4.53 & -2.864 & 0.220 & 8.202 & $0.004 * *$ & 0.33 \\
\hline $\mathrm{C} 8$ & 4.05 & 4.20 & 1.991 & 0.045 & 3.963 & 0.041 * & 0.28 \\
\hline C9 & 4.21 & 4.43 & -3.140 & 0.149 & 9.859 & $0.002 * *$ & 0.35 \\
\hline $\mathrm{C} 10$ & 4.16 & 4.51 & -3.750 & 0.254 & 14.060 & $0.000^{* *}$ & 0.54 \\
\hline C11 & 4.03 & 4.29 & -2.876 & 0.201 & 8.269 & $0.004^{* *}$ & 0.43 \\
\hline C12 & 3.27 & 3.21 & 0.560 & 0.571 & 0.314 & 0.576 & \\
\hline C13 & 3.20 & 3.23 & -0.340 & 0.364 & 0.116 & 0.734 & \\
\hline $\mathrm{C} 14$ & 3.38 & 3.34 & 0.433 & 0.342 & 0.188 & 0.665 & \\
\hline C15 & 3.21 & 3.20 & -0.822 & 0.899 & 0.675 & 0.412 & \\
\hline C16 & 3.09 & 3.21 & -1.650 & 0.174 & 2.723 & 0.100 & \\
\hline
\end{tabular}

V.: variable; $W$ : women, $M$ : men; According to Levene statistics, equal variances for all results $(p>0.05)$; $p<0.05$; ** $p<0.01$.

Likewise, the results returned in the analysis of variance show the existence of significant differences between women and men $(p<0.05)$ in the variables related to the importance given and training in teaching and digital skills $(p=0.048, p=0.004, p=0.041, p=0.002, p=0.000, p=0.004)$. In general, for these variables, there are differences between genders with higher mean values, in all variables, in men, except in item C6, related to the importance of teaching competence and the TCD in teacher training (,$+ M=4.96 ; \sigma^{\top}, M=4.21$ ). These differences register, however, an effect size between small and medium, a circumstance that confirms the bias of the gender's explanatory capacity. In contrast, the differences identified in relation to the educational importance given to TDC reach a high effect size $(d=1.55)$, where gender is a priority factor.

On issues related to the training of university teachers in digital manipulative and didactic skills, there is no gender difference.

\subsection{Comparative Analysis by Country and University Institution}

According to the results obtained (Table 5), the absence of significant differences between the country and the university institution of origin in the variables analyzed can be confirmed.

Indeed, the values obtained in the variables $\mathrm{C} 9, \mathrm{C} 10, \mathrm{C} 11, \mathrm{C} 12, \mathrm{C} 13, \mathrm{C} 14, \mathrm{C} 15$ and C16, in both countries, show that the hypothesis of equality of means, confirmed in the results of the t-test for these variables, cannot be rejected $(p>0.05)$.

Likewise, the analysis of variance confirms the absence of statistically significant differences between university institutions with $p$ values, in all variables analyzed, greater than $0.05(p>0.05)$. 
Table 5. T-test and ANOVA test according to country and university institution.

\begin{tabular}{cccccccc}
\hline & \multicolumn{7}{c}{ University Institution } \\
\cline { 2 - 8 } & Alicante & Burgos & Strasbourg & $\boldsymbol{t}$ & $\boldsymbol{p}$ & $\boldsymbol{F}$ & $\boldsymbol{p}$ \\
\hline C5 & 3.52 & 3.56 & 3.47 & 0.780 & 0.436 & 0.374 & 0.688 \\
C6 & 4.78 & 4.73 & 4.71 & 1.044 & 0.066 & 0.996 & 0.370 \\
C7 & 4.37 & 4.33 & 4.34 & 0.312 & 0.297 & 0.143 & 0.867 \\
C8 & 4.05 & 4.17 & 4.06 & 0.459 & 0.756 & 0.799 & 0.451 \\
C9 & 4.26 & 4.23 & 4.27 & -0.403 & 0.647 & 0.184 & 0.832 \\
C10 & 4.29 & 4.14 & 4.25 & -0.266 & 0.687 & 1.101 & 0.333 \\
C11 & 4.03 & 4.12 & 4.12 & -0.632 & 0.791 & 0.556 & 0.574 \\
C12 & 3.20 & 3.29 & 3.28 & -0.417 & 0.528 & 0.382 & 0.683 \\
C13 & 3.46 & 3.51 & 3.54 & -0.742 & 0.691 & 0.380 & 0.684 \\
C14 & 3.40 & 3.28 & 3.40 & -0.569 & 0.623 & 0.633 & 0.531 \\
C15 & 3.35 & 3.44 & 3.47 & -1.008 & 0.373 & 0.844 & 0.431 \\
C16 & 3.10 & 3.12 & 3.15 & -0.500 & 0.194 & 0.139 & 0.870 \\
\hline V.:
\end{tabular}

V.: variable; According to Levene statistics, equal variances for all results $(p>0.05)$.

\subsection{Correlation between Variables}

The results report a high correlation between the perceptions on the digital competence of university teachers and the adequate didactic implementation of technological tools, with values of $r=0.792$ and $r=0.754$ (Table 6).

Table 6. Bivariate Pearson correlations.

\begin{tabular}{|c|c|c|c|c|c|c|c|c|c|c|c|c|}
\hline & C5 & C6 & C7 & $\mathrm{C} 8$ & C9 & C10 & C11 & $\mathrm{C} 12$ & $\mathrm{C} 13$ & C14 & C15 & C16 \\
\hline C5 & 1 & & & & & & & & & & & \\
\hline C6 & 0.049 & 1 & & & & & & & & & & \\
\hline $\mathrm{C} 7$ & 0.097 * & 0.039 & 1 & & & & & & & & & \\
\hline $\mathrm{C} 8$ & 0.118 * & 0.053 & $0.449 * *$ & 1 & & & & & & & & \\
\hline C9 & $0.145^{* *}$ & $0.115^{* *}$ & $0.396^{* *}$ & $0.378^{* *}$ & 1 & & & & & & & \\
\hline C10 & -0.006 & 0.085 & $0.495^{* *}$ & $0.452 * *$ & $0.409 * *$ & 1 & & & & & & \\
\hline C11 & $0.249 *$ & 0.053 & $0.467^{* *}$ & $0.475^{* *}$ & $0.426^{* *}$ & $0.541^{* *}$ & 1 & & & & & \\
\hline C12 & $0.403^{* *}$ & 0.064 & $0.122 *$ & $0.158^{* *}$ & $0.159^{* *}$ & $0.260 * *$ & $0.233^{* *}$ & 1 & & & & \\
\hline C13 & $0.407^{* *}$ & 0.007 & $0.259 * *$ & $0.128 * *$ & 0.104 * & $0.562 *$ & $0.192 * *$ & $0.792 * *$ & 1 & & & \\
\hline C14 & $0.397^{* *}$ & 0.089 & $0.102 *$ & $0.181^{* *}$ & $0.135^{* *}$ & $0.218^{*}$ & $0.185^{* *}$ & $0.754^{* *}$ & $0.805^{* *}$ & 1 & & \\
\hline C15 & $0.428 * *$ & 0.059 & 0.101 * & $0.238 * *$ & $0.187^{* *}$ & $0.569 *$ & $0.226^{* *}$ & $0.572 * *$ & 0.722 ** & $0.710^{* *}$ & 1 & \\
\hline C16 & $0.375^{* *}$ & 0.090 & 0.154 & $0.148^{* *}$ & $0.153 * *$ & $0.134^{* *}$ & $0.157^{* *}$ & $0.566^{* *}$ & 0.592 ** & $0.574 * *$ & $0.727^{* *}$ & 1 \\
\hline
\end{tabular}

The same is true of the variables referring to the training of university teachers and the correct implementation of ICTs in teacher training plans $(r=0.805, r=0.722)$. Likewise, there is a high positive relationship when comparing the capacity of university teachers for the didactic implementation of technologies and digital content, and their knowledge about educational technologies $(r=0.727)$.

However, the consideration of the importance of initial and continuing training in the acquisition of teaching skills and digital competences at the training and professional stage shows a weak positive correlation with the TDC training of teachers $(r=0.064)$, with their ability to use ICT as a didactic-pedagogical resource $(r=0.007)$; with their aptitude to carry out an optimal curricular inclusion of technologies $(r=0.089)$; with the development of teaching-learning models capable of combining contents, didactics and ICT $(r=0.059)$, and with the knowledge of the technological-didactic tools existing in the market $(r=0.090)$.

Regarding the perceptions of digital competence as a teaching resource for future teachers, and the assessment of this same competence in university teachers and their ability to provide satisfactory training in it, positive relationships were found with a strong dependence between variables $(r=0.562$, $r=0.569$ ). 
Finally, there was a negative correlation $(r=-0.006)$ between students' expectations about their training in teaching skills and their self-perceptions in TDC.

\section{Discussion and Conclusions}

The results obtained show that Spanish and French teachers in training value positively their professional capacity in teaching and digital skills. These findings are similar to those obtained in other studies such as Sur, Ünal, and Iseries [31], where the inter-relationship between the need for digital training and its benefits for teaching is corroborated, or the analysis of Roig-Vila, Mengual-Andrés, Sterrantino, and Quinto [1], where the absence of difficulties for future teachers in the manipulative use of technologies for educational purposes is noted. This work is contrary to the results obtained in the research of Guillén-Gámez, Lugones, and Mayorga-Fernández [32], which concludes that future teachers of foreign languages, in this case, reach a medium-low level in digital teaching skills. Similar conclusions were reached in the study by Gudmundsdottir and Hatlevik [33], who identified low ICT training in a sample of 356 newly graduated Norwegian teachers.

In relation to the importance given to digital competences for teacher training, it is observed that participants attribute an outstanding relevance to their development in their bachelor's and master's training. This affirmation coincides with the results of similar research $[7,16,34,35]$, where it is shown that future teachers consider it necessary to be trained, specifically, in these competencies, in order to implement technological tools and emerging methodologies in the classroom in an operational and efficient manner. However, along the lines of other works [23-26], significant gender differences are identified, regardless of the country and university institution, with women attributing greater importance to their teacher training in digital skills. These values must be related to the differential self-perception that men and women have about their ability to manipulate the use of ICT [36]. In this sense, these differences have been recently confirmed in studies such as Flores-Lueg and Roig-Vila [37], who showed, in a sample of 175 future teachers, that men obtained higher results in their self-perceived level of digital competence and, in particular, in the technical, didactic, social, ethical and legal dimensions; or in Cabezas, Casillas, Sánches-Ferreira and Teixeira [38], where the existence of significant differences in digital competence perceptions in favor of men is verified. This reality is corroborated by active primary education teachers [39]. However, many studies are beginning to show the existence of a reduction in the gender digital gap through the use of social networks [40,41], and in the rest of digital competences [42-48].

The dependency relationships between the variables analyzed in this research confirm, in line with Pozos and Tejada [46], and García, Rebollo, and García [49], the absence of an adequate mastery of digital skills, linked to the teaching role, in university professors. These results coincide with those obtained in the study by Colás-Bravo, Conde-Jiménez and Reyes-de-Cózar [50] in the context of secondary education, where it is concluded that "teachers through their educational practice develop the digital competence of their students at an intermediate level" (p. 31). This may be due to the fact that future teachers tend to interpret the manipulative use of technologies and their digital training as teachers in two different areas, disassociating the teaching competences from the digital competences of teachers. These results coincide with those analyzed in the works of Muñoz, González and Fuentes [51], and of Castañeda, Esteve and Adell [17], in which it is stated that university teachers have elementary knowledge of basic technological tools (word processors, spreadsheets and databases) and, to a lesser extent, of their technological and didactic implementation in the classroom. In this line, despite the positive consideration of ICTs in their training as teachers, the assessments given by future teachers to their trainers show the scarce incorporation of technologies in the curricula.

If we relate these results to the six competence levels and the 21 descriptors developed for the five areas established in the Common Framework for Digital Teaching Competence [13], we can see that future teachers value the acquisition of competences and digital teaching skills positively and that, according to Marín, Vázquez and Cabero [52] and Castañeda, Esteve and Adell [17], the special importance attributed to the didactic potential of ICT and the different ways of implementing them in 
training contexts is confirmed. In this sense, the study by Girón, Cózar and González-Calero [53] on the evaluation of the TDC based on this model in a sample of 177 university students of infant and primary education, shows the need for greater training in ICT in these degrees.

These evidences allow us to verify that, in spite of the positive self-perception in digital competences of the future teachers, there is an unfavorable valuation of the competences and digital skills of their trainers. Despite the efforts of the educational administrations to advance in the improvement, training and implementation of learning and knowledge technologies (LKTs) in the university curricula, there is still a long way to go to meet the current demands of the ICS. This reality was confirmed in Sipilä's study [54], which stated that the majority of Finnish teachers $(n=292)$ do not have the means or knowledge to fully implement ICT in the promotion of digital learning. There are still contradictions, therefore, between the formal structures of educational institutions and classroom practices.

The importance of digital literacy and digital skills training lies in its critical influence on educational innovation. Skills related to digital competence such as retrieving, selecting, creating or exchanging digital content and experiences in virtual environments are, in fact, particularly relevant in educational improvement and in the implementation of active methodologies based on the principles of cooperative learning [45].

In spite of the potential contributions of these results to the knowledge of future teachers' self-perception about their TDC and the educational perception of their university studies, this study should be completed with the application of qualitative techniques capable of triangulating and deepening its conclusions. In this new study, it would also be necessary to assess the potential impact of age, teaching experience, knowledge of ICTs and attitude towards them by future teachers, factors outlined in other studies [55].

Likewise, the empirical evidence on the validation of the instrument applied and provided in this study (content validity, construct validity -EFA-, and internal consistency and reliability of the subscales) could be completed with the performance of a Confirmatory Factor Analysis (CFA), in order to corroborate the validity of the factor structure previously obtained (EFA). However, according to Pérez-Gil, Chacón and Moreno [56], given that the factorial structure resulting from the EFA is one of the possible solutions derived from the data matrix, it is foreseeable that, in another sample extracted from the same reference population, the structure and, therefore, the theoretical deductions initially obtained, can be confirmed.

This study shows the existence of a close relationship between the level of competence of university teachers and the digital training of future teachers. As indicated by Cabero and Ruiz [16], the change in education will be possible by transforming, initially, the technological conceptions of university teachers and, as already indicated by Mishra and Koehler [57], by carrying out an effective inclusion of technology in the educational context, or by offering greater opportunities to students to develop and acquire digital competences [58-60]. In this sense, according to the results obtained in their study, we agree with Miguel-Revilla, Martínez-Ferreira and Sánchez-Agustí [61] in affirming the need to "re-examine how the digital competence of educators is addressed in teacher training, and the relevance of stressing the influence of teacher education curriculum and its orientation" (p. 8). Consequently, considering the research results obtained in this field, it is necessary to stimulate more designs of teaching intervention based on theoretical and methodological principles such as those proposed by the TPACK (Technological Pedagogical Content Knowledge) model, and to generate new measuring instruments capable of informing curricular decisions and an evaluation of the operational and effective integration of digital technology [62].

Author Contributions: Conceptualization, D.O.-S. and I.M.G.-T.; methodology, D.O.-S. and I.M.G.-T.; software, D.O.-S. and I.M.G.-T.; validation, D.O.-S. and I.M.G.-T.; formal analysis, D.O.-S. and I.M.G.-T.; investigation, D.O.-S., I.M.G.-T., M.T., and C.P.-G.; resources, D.O.-S., I.M.G.-T., M.T., and C.P.-G.; data curation, D.O.-S. and I.M.G.-T.; writing — original draft preparation, D.O.-S. and I.M.G.-T.; writing-review and editing, D.O.-S.; visualization, D.O.-S., I.M.G.-T., M.T., and C.P.-G.; supervision, D.O.-S., I.M.G.-T., M.T., and C.P.-G.; project administration, D.O.-S., I.M.G.-T., M.T., and C.P.-G.; funding acquisition, D.O.-S., I.M.G.-T., and C.P.-G. All authors have read and agreed to the published version of the manuscript. 
Funding: This research received no external funding.

Acknowledgments: This research has been conducted under the Educational Research Projects REDESI3CE20184351 and REDES-I3CE-2017-4159 (University of Alicante, Spain), and the Research Group Recognized in Didactics of History and Social Sciences (DHISO) (University of Burgos, Spain).

Conflicts of Interest: The authors declare no conflict of interest.

\section{References}

1. Roig-Vila, R.; Mengual-Andrés, S.; Sterrantino Asmussen, C.; Quinto Medrano, P. Attitudes toward technological resources in the classroom of the future teachers. @tic Revista d'Innovació Educativa 2015, 15, 12-19. [CrossRef]

2. Álvarez, J.; Gisbert-Cervera, M. Information Literacy Grade of Secondary School Teachers in Spain. Beliefs and Self-Perceptions. Comunicar 2015, 23, 187-194. [CrossRef]

3. De Benito, B.; Darder, A.; Lizana, A.; Marín, V.; García, J.M.; Salinas, J. Agregación, filtrado y curación para la actualización docente. Pixel-Bite 2013, 42, 157-169.

4. Ortega-Sánchez, D.; Gómez Trigueros, I.M. Las WebQuests y los MOOCs en la enseñanza de las Ciencias Sociales y la formación del profesorado de Educación Primaria. Rev. Electrónica Interuniv. De Form. Del Profr. 2017, 20, 205-220. [CrossRef]

5. Perrenoud, P. Diez Nuevas Competencias Para Enseñar; Graó: Barcelona, Spain, 2004.

6. Tejada, J. Competencias docentes. Profr. Rev. De Curric. Y Form. Del Profr. 2009, 13, 1-15.

7. Ríos, J.M.; Gómez, E.R.; Rojas, M.P. Valoración de competencias TIC del profesorado universitario: Un caso en Chile. Pixel-Bit 2018, 52, 55-65. [CrossRef]

8. Symozas, R.; Nieto, E. (Coords.); Evaluación De La Competencia Digital Docente; Síntesis: Madrid, Spain, 2017.

9. Tourón, J.; Martín, D.; Asencio, N.; Pradas, S.; Íñigo, V. Validación de constructo de un instrumento para medir la competencia digital docente de los profesores (CDD). Rev. Española De Pedagog. 2018, 269, $25-54$. [CrossRef]

10. Europeo, P.; de la Unión Europea, C. Recomendación 2006/962/CE, De 18 De Diciembre, Sobre Las Competencias Clave Para El Aprendizaje Permanente. D. Of. de la Unión Eur. 2006, 394, 10-18.

11. Cabero-Almenara, J.; Palacios-Rodríguez, A. Marco Europeo de Competencia Digital Docente «DigCompEdu». Traducción y adaptación del cuestionario «DigCompEdu Check-In». Edmetic 2019, 9, 213-234. [CrossRef]

12. de la Unión Europea, C. Recomendación Del Consejo, De 22 De Mayo De 2018, Relativa A Las Competencias Clave Para El Aprendizaje Permanente. D. Of. de la Unión Eur. 2018, 189, 1-13.

13. INTEF. Marco Común De Competencia Digital Docente; Instituto Nacional de Tecnologías Educativas y Formación del Profesorado: Madrid, Spain, 2017.

14. Redecker, C.; Punie, Y. European Framework for the Digital Competence of Educators: Digcompedu; Publications Office of the European Union: Luxembourg City, Luxembourg, 2017.

15. Cabero, J.; Marín, V. Miradas sobre la formación del profesorado. TIC Rev. Venez. De Inf. Tecnol. Y Conoc. 2014, 11, 11-12.

16. Cabero, J.; Ruiz, J. Las Tecnologías de la Información y Comunicación para la inclusión: Reformulando la brecha digital. IJERI Int. J. Educ. Res. Innov. 2017, 9, 16-30.

17. Castañeda, L.; Esteve, F.; Adell, J. ¿Por qué es necesario repensar la competencia docente para el mundo digital? Rev. De Educ. Distancia (RED) 2018, 56. [CrossRef] [PubMed]

18. Ortega-Sánchez, D.; Gómez-Trigueros, I. Massive Open Online Courses in the Initial Training of Social Science Teachers: Experiences, Methodological Conceptions, and Technological Use for Sustainable Development. Sustainability 2019, 11, 578. [CrossRef]

19. Ferrés, J.; Masanet, M.J. La Educación Mediática En La Universidad Española; Gedisa: Barcelona, Spain, 2015.

20. European Commission/EACEA/Eurydice. Digital Education at School in Europe. Eurydice Report; Publications Office of the European Union: Luxembourg City, Luxembourg, 2019.

21. Lemon, N.; Garvis, S. Pre-service teacher self-efficacy in digital technology. Teach. Teach. 2015, 22, $387-408$. [CrossRef]

22. Pardo, A.; Ruiz, M.A.; San-Martín, R. Análisis De Datos En Ciencias Sociales Y De La Salud I; Síntesis: Madrid, Spain, 2015. 
23. Cortina-Pérez, B.; Gallardo-Vigil, M.; Jiménez-Jiménez, M.; Trujillo-Torres, J. Digital illiteracy: A challenge for 21st century teachers/El analfabetismo digital: Un reto de los docentes del siglo XXI. Cult. Y Educ. 2014, 26, 231-264. [CrossRef]

24. Silva, J.; Usart, M.; Lázaro-Cantabrana, J. Teacher's digital competence among final year Pedagogy students in Chile and Uruguay. Comunicar 2019, 27, 33-43. [CrossRef]

25. Suárez Rodríguez, J.; Almerich, G.; Gargallo López, B.; Aliaga, F. Las competencias del profesorado en TIC: Estructura básica (the competencies of teachers in ICT: Basic structure). Educ. XX1 2013, 16, 39-62. [CrossRef]

26. Zhong, Z. From access to usage: The divide of self-reported digital skills among adolescents. Comput. Educ. 2011, 56, 736-746. [CrossRef]

27. Argibay, J.C. Muestra en investigación cuantitativa. Subj. Y Procesos Cogn. 2009, 13, 13-29.

28. Otzen, T.; Manterola, C. Técnicas de Muestreo sobre una Población a Estudio. Int. J. Morphol. 2017, 35, 227-232. [CrossRef]

29. Zamora-Polo, F.; Sánchez-Martín, J.; Corrales-Serrano, M.; Espejo-Antúnez, L. What Do University Students Know about Sustainable Development Goals? A Realistic Approach to the Reception of this UN Program Amongst the Youth Population. Sustainability 2019, 11, 3533. [CrossRef]

30. Morales, P.; Usosa, B.; Blanco, A. Construcciones De Escalas De Actitudes Tipo Likert; La Muralla: Madrid, Spain, 2003.

31. Sur, E.; Ünal, E.; Iseries, K. Primary School second grade teachers' and students' opinions on media literacy. Comunicar 2014, 21, 119-127. [CrossRef]

32. Guillén-Gámez, F.; Lugones, A.; Mayorga-Fernández, M.; Wang, S. ICT use by pre-service foreign languages teachers according to gender, age and motivation. Cogent Educ. 2019, 6, 1-17. [CrossRef]

33. Gudmundsdottir, G.; Hatlevik, O. Newly qualified teachers' professional digital competence: Implications for teacher education. Eur. J. Teach. Educ. 2017, 41, 214-231. [CrossRef]

34. Prendes-Espinosa, M.; Castañeda-Quintero, L.; Gutiérrez-Porlán, I. ICT competences of future teachers. Comunicar 2010, 18, 175-182. [CrossRef]

35. Cabezas, M.; Casillas, S.; Pinto, A.M. Percepción de los alumnos de Educación Primaria de la Universidad de Salamanca sobre su competencia digital. EDUTEC Rev. Electrónica De Tecnol. Educ. 2014, 48, a275.

36. Erdogan, A.; Sahin, I. Relationship between math teacher candidates' Technological Pedagogical and Content Knowledge (TPACK) and achievement levels. Procedia Soc. Behav. Sci. 2010, 2, 2707-2711. [CrossRef]

37. Flores-Lueg, C.; Roig-Vila, R. El género y su incidencia en el nivel de competencia digital autopercibido por estudiantes de Pedagogía. Int. J. Educ. Res. Innov. (IJERI) 2017, 8, 79-96.

38. Cabezas, M.; Casillas, S.; Sánches-Ferreira, F.; Teixeira, L. ¿Condicionan el género y la edad el nivel de competencia digital? Un estudio con estudiantes universitarios. Fonseca J. Commun. 2017, 15, 109-125. [CrossRef]

39. Romero, S.J.; Hernández, C.J.; Ordóñez, X.G. La competencia digital de los docentes en educación primaria: Análisis cuantitativo de su competencia, uso y actitud hacia las nuevas tecnologías en la práctica docente. Rev. Tecnol. Cienc. Y Educ. 2016, 4, 33-51.

40. Clipson, T.W.; Wilson, S.A.; Dufrene, D.D. The Social Networking Arena: Battle of the Sexes. Bus. Commun. Q. 2012, 75, 64-67. [CrossRef]

41. Mazman, S.G.; Usluel, Y.K. Gender Differences in Using Social Networks. TOJET Turk. Online J. Educ. Technol. 2011, 10, 133-139.

42. Centeno Moreno, G.; Cubo Delgado, S. Evaluación de la competencia digital y las actitudes hacia las TIC del alumnado universitario. Rev. De Investig. Educ. 2013, 31, 517-536. [CrossRef]

43. Cózar, R.; Roblizo, M.J. La competencia digital en la formación de los futuros maestros: Percepciones de los alumnos de los Grados de Maestro de la Facultad de Educación de Albacete. Relatec. Rev. Latinoam. De Tecnol. Educ. 2014, 13, 119-133.

44. Hatlevik, O.; Christophersen, K. Digital competence at the beginning of upper secondary school: Identifying factors explaining digital inclusion. Comput. Educ. 2013, 63, 240-247. [CrossRef]

45. Martínez-Bravo, M.C.; Sádaba, C.H.; Serrano-Puche, J. Desarrollo de competencias digitales en comunidades virtuales: Un análisis de "ScolarTIC". Prism. Soc. Rev. De Cienc. Soc. E Investig. Soc. 2018, 20, 129-159.

46. Pozos Pérez, K.; Tejada Fernández, J. Competencias Digitales en Docentes de Educación Superior: Niveles de Dominio y Necesidades Formativas. Rev. Digit. De Investig. En Docencia Univ. 2018, 12, 59-87. [CrossRef] 
47. Roblizo Colmenero, M.; Cózar Gutiérrez, R. Usos y competencias en TIC en los futuros maestros de educación infantil y primaria: Hacia una alfabetización tecnológica real para docentes. Píxel-Bit Rev. De Medios Y Educ. 2015, 23-39.

48. Vázquez-Cano, E.; Marín, V.; Maldonado, G.A.; García-Garzón, E. La competencia digital del alumnado universitario de Ciencias Sociales desde una perspectiva de género. Prism. Soc. Rev. De Cienc. Soc. E Investig. Soc. 2017, 19, 347-367.

49. García Pérez, R.; Rebollo Catalán, Á.; García Pérez, C. Relación entre las preferencias de formación del profesorado y su competencia digital en las redes sociales. Bordón Rev. De Pedagog. 2016, 68, 137-153. [CrossRef]

50. Colás-Bravo-Bravo, P.; Conde-Jiménez, J.; Reyes-de-Cózar, S. The development of the digital teaching competence from a sociocultural approach. Comunicar 2019, 27, 21-32. [CrossRef]

51. Muñoz, P.C.; González, M.; Fuentes, E.J. Competencias tecnológicas del profesorado universitario: Análisis de su formación en ofimática. Educ. XXI 2011, 14, 157-188.

52. Marín Díaz, V.; Vázquez Martínez, A.; Llorente Cejudo, M.; Cabero Almenara, J. La alfabetización digital del docente universitario en el espacio europeo de educación superior. Edutec. Rev. Electrónica De Tecnol. Educ. 2012, 39, a194.

53. Girón Escudero, V.; Cózar Gutiérrez, R.; González-Calero Somoza, J. Análisis de la autopercepción sobre el nivel de competencia digital docente en la formación inicial de maestros/as. Rev. Electrónica Interuniv. De Form. Del Profr. 2019, 22, 193-218. [CrossRef]

54. Sipilä, K. Educational use of information and communications technology: teachers' perspective. Technol. Pedagog. Educ. 2013, 23, 225-241. [CrossRef]

55. Lawrence, J.; Tar, U. Factors that influence teachers' adoption and integration of ICT in teaching/learning process. Educ. Media Int. 2018, 55, 79-105. [CrossRef]

56. Pérez-Gil, J.; Chacón, S.; Moreno, R. Validez de constructo: El uso de análisis factorial exploratorio-confirmatorio para obtener evidencias de validez. Psicothema 2000, 12, 442-446.

57. Mishra, P.; Koehler, M.J. Technological pedagogical content knowledge: A framework for integrating technology in teacher knowledge. Teach. Coll. Rec. 2006, 108, 1017-1054. [CrossRef]

58. Gómez-Trigueros, I.M.; Ruiz-Bañuls, M.; Ortega-Sánchez, D. Digital Literacy of Teachers in Training: Moving from ICTs (Information and Communication Technologies) to LKTs (Learning and Knowledge Technologies). Educ. Sci. 2019, 9, 274. [CrossRef]

59. Ortega-Sánchez, D.; Gómez-Trigueros, I.M. Didactics of Historical-Cultural Heritage QR Codes and the TPACK Model: An Analytic Revision of Three Classroom Experiences in Spanish Higher Education Contexts. Educ. Sci. 2019, 9, 117. [CrossRef]

60. Ortega-Sanchez, D.; Gomez-Trigueros, I. MOOCs and NOOCs in the Training of Future Geography and History Teachers: A Comparative Cross-Sectional Study Based on the TPACK Model. IEEE Access 2020, 8, 4035-4042. [CrossRef]

61. Miguel-Revilla, D.; Martínez-Ferreira, J.; Sánchez-Agustí, M. Assessing the digital competence of educators in social studies: An analysis in initial teacher training using the TPACK-21 model. Australas. J. Educ. Technol. 2020, 36, 1-12. [CrossRef]

62. Herring, M.; Koehler, M.; Mishra, P. (Eds.) Handbook of Technological Pedagogical Content Knowledge (TPACK) for Educators, 2nd ed.; Routledge: New York, NY, USA, 2016.

Publisher's Note: MDPI stays neutral with regard to jurisdictional claims in published maps and institutional affiliations.

(C) 2020 by the authors. Licensee MDPI, Basel, Switzerland. This article is an open access article distributed under the terms and conditions of the Creative Commons Attribution (CC BY) license (http://creativecommons.org/licenses/by/4.0/). 